Marquette University

e-Publications@Marquette

Economics Faculty Research and Publications

Economics, Department of

$1-1-2000$

\title{
American Macromanagement Issues and Policy
}

Joseph P. Daniels

Marquette University, joseph.daniels@marquette.edu

John B. Davis

Marquette University, john.davis@marquette.edu

Published version. "American Management Issues and Policy," in Globalizing America: The USA in World Integration. Eds. Thomas L. Brewer and Gavin Boyd. Cheltenham, ENG: Edward Elgar Publishing, 2000: 190-210. Publisher Link. (c) 2000 Edward Elgar Publishing. Used with permission. 


\section{American macromanagement issues and policy}

\section{Joseph P. Daniels and John B. Davis}

\section{INTRODUCTION}

Technological gains, advances in communications, and lower transportation costs, combined with trade liberalization efforts of post-war multilateral institutions, such as the General Agreement on Tariffs and Trade (GATT), the World Trade Organization (WTO) and the International Monetary Fund (IMF), as well as regional and unilateral actions, have increasingly opened nations to trade and capital flows creating a dynamic global market-place. Though liberalization has faced numerous obstacles and advanced at an uneven pace, it has advanced. As illustrated in Figure 9.1, over the last two decades world trade in goods and services has grown in excess of an annual average rate of 5

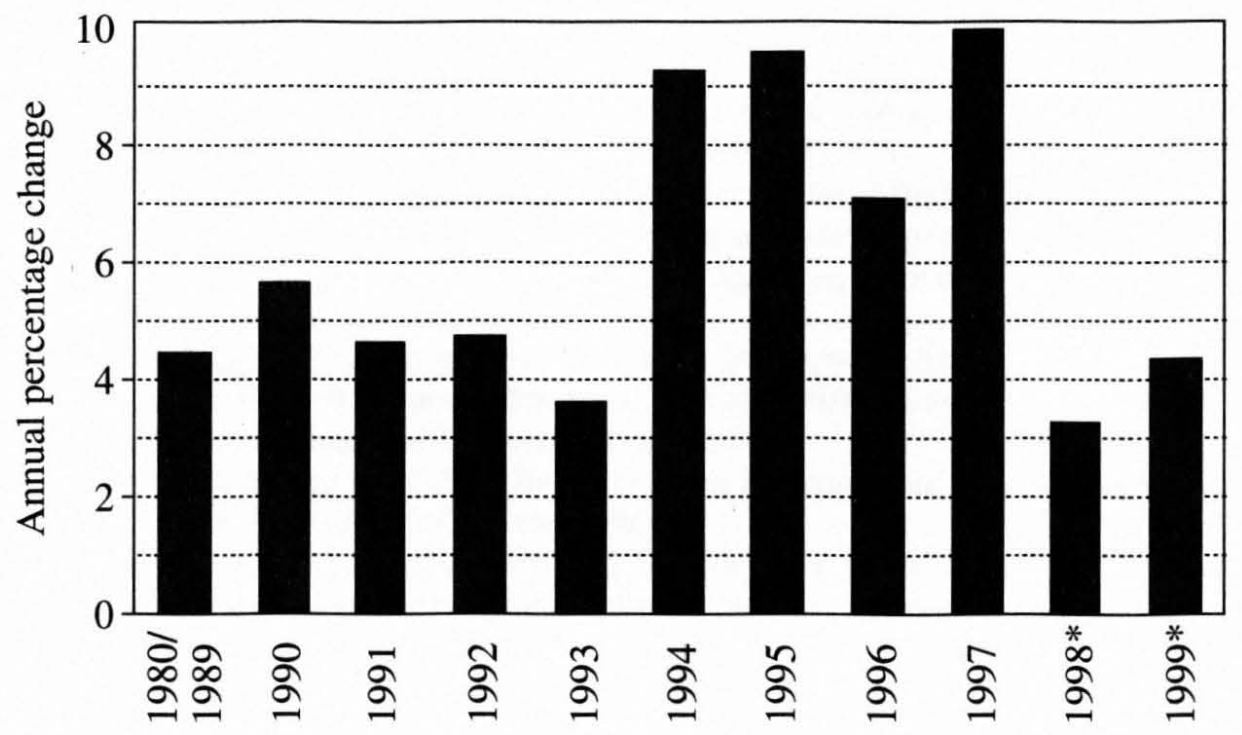

Note: * Projected, IMF.

Figure 9.1 Volume of world trade: goods and services, 1980/89-99 
per cent. In the early 1990s, in spite of a US economy in recession and stagnant European economies, the volume of world trade increased at a rate of 3 per cent or more each year, and by the middle 1990s it approached double digits. Due to the Asian financial crises of 1997, projections for growth of world trade are much smaller than the actual rates of the middle 1990s, yet they still are positive and in excess of 3 per cent a year.

Even the United States, the largest individual economy, has become more dependent on and integrated with foreign markets. As pointed out by John Kirton in Chapter 2, this has occurred even though most Americans, 56 per cent versus 37 per cent according to a recent poll conducted by the Angus Reid Group (The Economist, 1999, and as cited by Kirton, Chapter 2), view protectionism over free trade as best for US prosperity. In Chapter 1, Figure 1.1, Pryor examines the extent of globalization of the US real sector using exports and imports as a per cent of GDP. Focusing on the evidence for the last two decades we see that, following the depreciation of the US dollar from its historic high valuation in 1985, imports relative to GDP have increased from approximately 10 per cent to over 13 per cent and exports relative to GDP have increased from approximately 7.25 per cent to 12 per cent. As we point out later in this chapter, however, this type of measure is likely to underestimate the extent of globalization as it masks the increased trade in intermediate goods and inputs that reflects companies' decisions to outsource increasing amounts of their production processes.

The increasing integration of the United States economy into the world economy at the end of the 20th century none the less needs to be understood in part within the context of US domestic economic policy issues. The USA, like Japan, combines a large domestic economy with a ratio of trade to GDP that is small compared to other OECD countries. This means that domestic economic issues are generally the primary concern of policy-makers, and that trade policy questions are often formulated in terms of domestic issues. This focus is sometimes overlooked on account of the strong commitment on the part of the USA since World War II to a liberal international trading order. But most individuals who come to play a role in US policy-making towards the international economy first spend years being involved in debates over domestic economic questions, and this later plays a role in framing their thinking about international economic policy.

In this chapter, we describe some of the macroeconomic challenges facing the American economy at the end of the 20th century that result from increasing globalization. We focus on issues that tend to reflect the special position of the USA in the world economy today, rather than issues shared with other OECD countries, in order to specifically describe how the American macroeconomy may differ from other countries and, therefore, how US macromanagement strategies differ. In particular, this chapter offers an ex- 
amination of a specific concern in the issue areas of balance of payments and exchange rate management, monetary policy, fiscal policy and trade policy. Hence, the first of these issues are by nature macroeconomic in the usual sense of the term, while others are more microeconomic in nature. Our main example of the former concerns the inconsistent attention given to the exchange value of the dollar. Because the US government is able to finance deficit spending solely in dollars, US budget policy has often been carried out without attention to the consequences of changes in the dollar's value. We also consider the euro's challenge to US dollar hegemony and the spillover effects of US monetary policy.

Our main example of the latter concerns the relatively high degree of decentralization and flexible character of US labour markets. Though changes in US labour markets, specifically in regard to wage dispersion and inequality, may be largely caused by forces independent of globalization, they are none the less perceived by many people in the USA as being related to the integration of the USA into the world economy. Here, in contrast to a past policy of neglect towards the value of the dollar at the macro level, there may be a tendency for policy-makers to become preoccupied with the connection between trade and income. The intensity of the debate over NAFTA is an illustration of this. To the extent that falling wages for low-skilled workers requires trade adjustment assistance, there are implications for fiscal policy. Hence, fiscal solutions are necessary in order to avoid pressure to use second-best commercial policies.

In this chapter we thus examine four important economic challenges faced by US policy-makers that fit in the issue areas of balance-of-payment, exchange rate, monetary policy and fiscal policy management, and that result from globalization of the US economy. We begin in the next section by considering the implications of exchange rate movements for US industries and US balance-of-payments performance and then turn to the question of whether the USA ought to adopt a unified policy toward exchange rate management. The next section considers the issue of spill-over effects of US monetary policies on foreign economies, concentrating on the case of Mexico. The section after that examines the fiscal challenges that result from reduced seigniorage revenues due to the birth of the euro. The penultimate section turns from macro to micro, and considers the distribution of welfare gains from increased trade liberalization and the inequality of income resulting. The final section offers conclusions regarding the overall character and direction of American macromanagement in a period of increasing globalization. 


\section{CURRENT ACCOUNT AND THE VALUE OF THE DOLLAR}

Randall Henning (1994) describes US exchange rate policy, in contrast to German and Japanese policy, as having been less consistent over time evolving through cycles of neglect and activism - and less conscious of the competitive ramifications of currency valuation. Recently, US Secretary Robert Rubin's approach to exchange rate policy was described as 'intervening in currency markets rarely, but like a ton of bricks when he does' (Hirsh, 1997). Henning argues that in the United States, the private sector is 'fractionalized' and therefore is unable to communicate a clear preference for external monetary and exchange rate policy. If the private sector could demonstrate a clear preference on exchange rate policy, then that preference could anchor policy and lend it continuity.

Figure 9.2 illustrates the nominal and real effective exchange values (trade weighted) of the US dollar for the past two decades, and thus reveals the currency instability that results from inconsistent policies. From 1981 to 1985, the dollar made a remarkable run, reaching unprecedented highs in both nominal and real value. The cause of the rise was primarily a mismatch of domestic monetary and fiscal policies and a mismatch of US policies with its major trading partners. Monetary policy was tight in order to stamp out inflation and fiscal policy was loose, with tax cuts combined with structural deficits resulting from increased defence spending. Both actions caused nominal and real US interest rates to skyrocket, attracting foreign capital inflows and causing the dollar to appreciate.

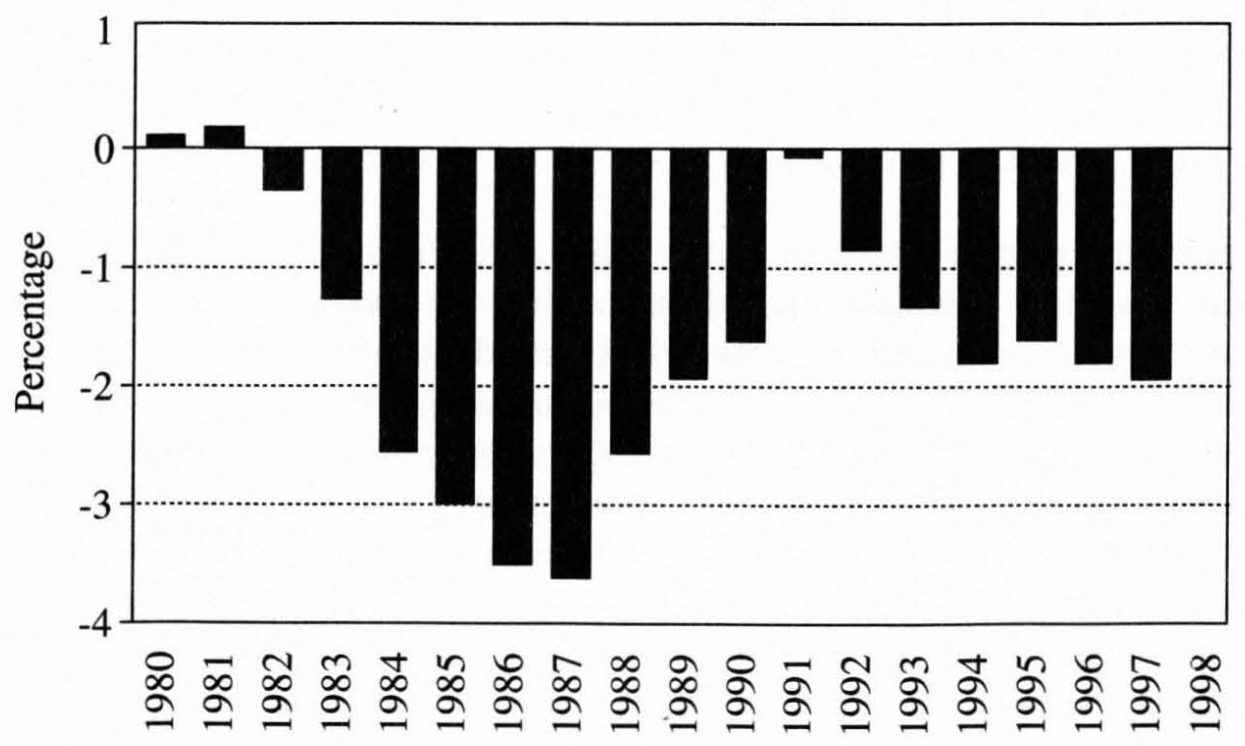

Figure 9.2 US current account balance, 1980-98(\% GDP) 


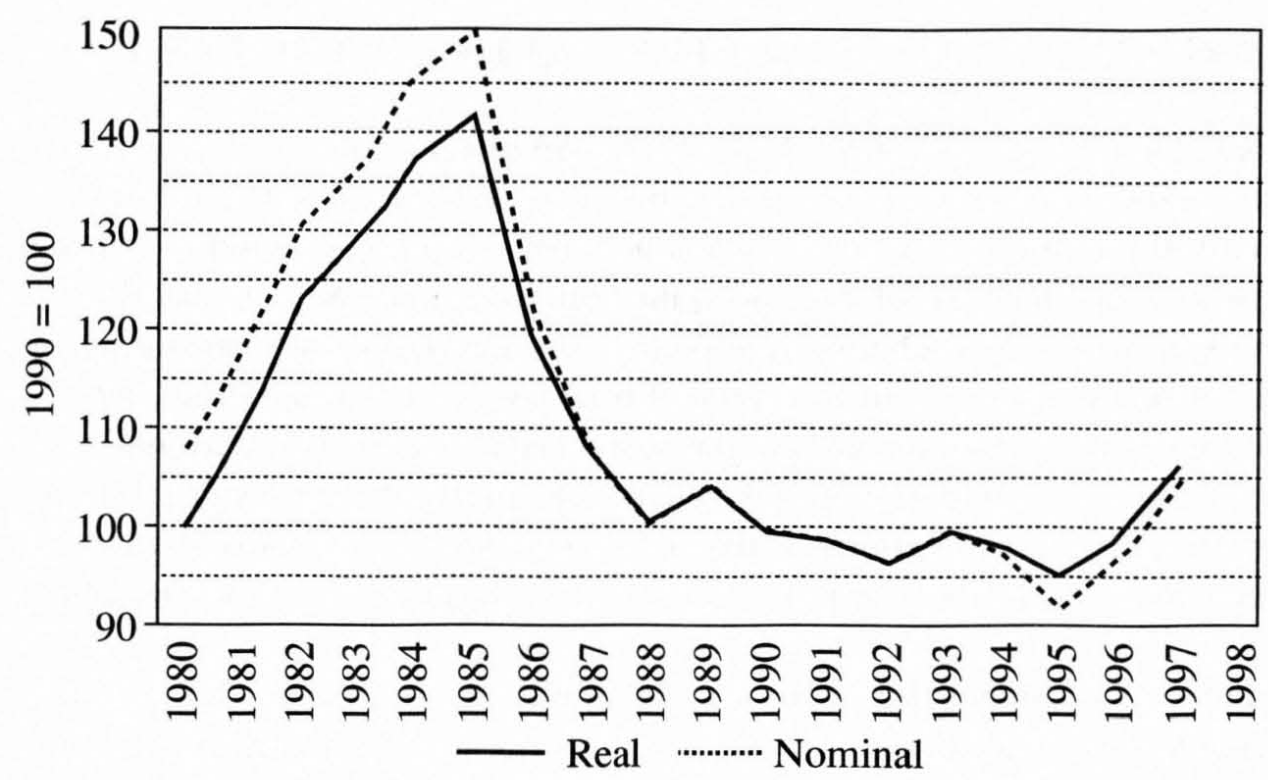

Figure 9.3 US dollar effective exchange value: nominal and real, 1980-98

As shown in Figure 9.3 the dollar appreciation reversed a modest surplus at the beginning of the 1980s and the current account deficit eventually widened to over 3.5 per cent of GDP in 1987 before declining following the depreciation of the dollar in 1987. The late 1980s to the mid-1990s was a period of general depreciation of the dollar and a decline of the US current account deficit, until 1992 when the deficit began to widen again. ${ }^{1}$ With a strengthening US economy, the dollar began to appreciate again in the mid-1990s. The current account deficit widened as well, and was magnified by the collapse of the East Asian economies in late 1997.

\section{Interpreting the Current Account Deficit}

The principal problem with an appreciating dollar and a widening current account deficit is that they often lead to cries for protection from cheap imports and unfair pricing from abroad. Hence, the deficit provides political 'cover' for policy-makers who choose to pursue second-best policies of trade protection as opposed to less popular macroeconomic strategies. Higgins and Klitgaard (1998) argue, however, that from a macroeconomic perspective the mounting current account deficit need not necessarily mean lower employment levels overall. Lower domestic employment in specific sectors may indeed result from higher end-use imports. This, however, can be offset by the employment generated by the inflow of job-creating foreign capital into the United States. The evidence summarized by the authors indicates that US multinationals produce more than $\$ 500$ billion in goods and services abroad 
annually rather than producing them in the United States. On the other hand, in 1997 alone the United States was the recipient of $\$ 255$ billion in net investment inflows. In addition, the use of imported inputs may allow firms to shift their capacity from low profit margin operations at the front of the production process to higher profit margin operation nearer the end of the production process, thereby raising wages. This is evident in the steel industry where, during the 1980 s, US firms reduced their capacity for manufacturing slab steel and increased their capacity for rolled finished steel products by relying on imported slab steel.

The relationship between a current account deficit and capital inflows can be better understood in terms of the national income and production accounts. By definition, the current account $C A$ equals the sum of the gap between domestic private saving $S$ and private domestic investment $I$ and the gap between taxes $T$ and government spending $G$ - the fiscal balance $(T-G)$ - expressed as

$$
C A=(S-I)+(T-G) .
$$

Additionally, domestic private saving is equivalent to the sum of private domestic investment spending, the fiscal balance, and the accumulation of foreign financial assets $F A$,

$$
S=I+(G-T)+F A .
$$

Combining the two equations, it is shown that the current account balance which equals the difference between private and public savings and private investment spending - is equal to the accumulation of foreign assets,

$$
C A=S+(T-G)-I=F A .
$$

Hence, if private saving exceeds the sum of private investment spending and the fiscal deficit, a current account surplus results and the nation is accumulating foreign assets. If, on the other hand, domestic private saving does not match private domestic investment and the fiscal deficit, a current account deficit results and the nation borrows from abroad.

Currently, US private saving is not sufficient to meet desired domestic private investment, which is job creating. The fall in private saving and the rise in domestic private investment necessitates the inflow of foreign capital. As argued by Higgins and Klitgaard (1998, p. 4), therefore, the current account deficit can be viewed as 'a reflection of the need for foreign capital to sustain the economy'. By viewing the current account deficit as a macroeconomic outcome, we can conclude that, in general terms, policy-makers have two 
options in reducing the need for foreign capital inflows (other than reducing domestic private investment which would be undesirable): stimulate private saving and/or reduce the fiscal deficit. In the United States actions have been taken in both areas. The deficit has been reduced and it appears a true surplus may result for the next fiscal year. Policy actions to increase domestic saving, however, have been unsuccessful. For the third quarter of 1998, the US personal saving rate turned negative for the first time since the 1930s and, according to calculations by J.P. Morgan, the private saving rate has declined to its lowest level ever, with investment and consumption spending exceeding income by more than 4 per cent of GDP (The Economist, 1998). Obviously further attention by economists and policy-makers is needed in this area.

Because the current account deficit is large and persistent, it implies very large levels of debt. Large levels of foreign debt may affect the creditworthiness of a nation and impinge on its ability to finance investment via international capital markets. According to Humpage $(1998$, p. 2) 'the mere existence of these debts indicates neither profligacy nor an unstable situation'. What is important is whether a nation can service its debt. By the mid-1990s, the level of net international debt as a share of GDP for the United States was the third largest of all the G7 economies, yet US international debt only amounts to 16 per cent of GDP. Humpage concludes, therefore, that under current circumstances the United states could remain a net debtor forever.

In addition to the creditworthiness issues, large levels of foreign debt, in the long run, may mean either a reduced standard of living for future generations who have to repay the debt, or an increased standard of living if the capital inflows are invested in a manner that spurs future productivity gains. What is important here is whether the foreign capital inflows finance current consumption or investment. One way of determining this is to see if investment spending has increased with the capital inflows. In an early study of this issue, Faust (1989) claims that investment spending was unchanged during the 1980s. Based on more recent data though, Hakkio (1995) argues that US investment spending actually declined after 1992. Hence, the impact of the large and persistent current account deficits on future living standards remains somewhat unclear and yet the employment consequences appear to be less than desirable.

\section{Industry Level Effects of Exchange Rate Movements}

Henning's hypothesis on the fractionalization of American businesses in regard to currency valuation is perhaps best explained by the uneven effects of currency movements on profit and performance across industries and firms. The effects of currency movements on profitability and performance 
depend upon the degree of globalization of a particular industry. The typical measure of the extent of industry openness is the total of import and export sales as a per cent of domestic production (import plus export revenue divided by domestic production revenues). This particular measure, however, only considers the revenue and market share aspects of currency movements. As argued by Campa and Goldberg (1997), foreign shocks that impinge upon a domestic industry because of that industry's dependence on export sales and exposure to import competition can be offset in part by the use of imported inputs in the domestic production process. In other words, the effect on revenues may be offset by lower costs of imported inputs. The importance of intra-industry trade is incorporated in the creative approach to measuring globalization by Makhija and Williamson, Chapter 5 in this volume.

Campa and Goldberg calculate four different measures to determine the extent of globalization and 'external orientation' of an industry, that is, the degree to which an industry may be affected by foreign shocks, such as a dramatic currency swing. The authors' four measures, provided in Table 9.1, are: export share, the ratio of industry export revenues to industry shipments; import share, the ratio of imports to consumption; imported input share, imported inputs as a share of the value of production; and net external orientation, the difference between industry export share and imported input share. The measures, provided for 20 industry classifications, show that some industries, such as industrial machinery and instruments and related products, can be adversely affected by a dollar appreciation as they rely heavily on export revenues as indicated by a high export share. Industries such as leather products, petroleum products and printing and publishing are likely to benefit from a dollar appreciation as their export share is low relative to their use of imported inputs. Still others yet, such as transportation equipment and primary metal products, are likely to be little affected even though their export share is relatively high. This is because their imported input share is high as well and a dollar appreciation will lower the cost of imported inputs and offset the lower export revenues.

Subsequent empirical work by Goldberg and Crockett (1998) shows that producer profits and investment spending are likely to be hurt by a dollar appreciation in industries where the measure of external orientation is high. In regard to wages, the 1995 dollar appreciation constrained wages considerably in the chemicals, industrial machinery, electronic equipment and instruments industries: four of five industries with the highest net external orientation measures. The authors also find that in the mid-1980s - when the net orientation for US manufacturing was less than 2 per cent - a 10 per cent rise in the value of the dollar resulted in a 2.4 per cent average decline in the investment rate of manufacturing industries while in 1995 - when the net 
Table 9.1 External orientation

\begin{tabular}{|c|c|c|c|c|c|}
\hline Category & $\begin{array}{l}\text { Export } \\
\text { share }\end{array}$ & $\begin{array}{l}\text { Import } \\
\text { share }\end{array}$ & $\begin{array}{l}\text { Imported input } \\
\text { share }\end{array}$ & $\begin{array}{c}\text { External } \\
\text { orientation }\end{array}$ & $\begin{array}{l}\text { Industry } \\
\text { integration }\end{array}$ \\
\hline Food and kindred products & 5.9 & 4.2 & 4.2 & 1.7 & 10.1 \\
\hline Tobacco products & 14.9 & 0.6 & 2.1 & 12.8 & 17 \\
\hline Textile mill products & 7.6 & 9.1 & 7.3 & 0.3 & 14.9 \\
\hline Apparel and other textiles & 7.4 & 31.4 & 3.2 & 4.2 & 10.6 \\
\hline Lumber and wood products & 7.6 & 10.3 & 4.3 & 3.3 & 11.9 \\
\hline Furniture and fixtures & 5.5 & 14.1 & 5.7 & -0.2 & 11.2 \\
\hline Paper and allied products & 9 & 10 & 6.3 & 2.7 & 15.3 \\
\hline Printing and publishing & 2.4 & 1.6 & 3.5 & -1.1 & 5.9 \\
\hline Chemicals and allied products & 15.8 & 11 & 6.3 & 9.5 & 22.1 \\
\hline Petroleum and coal products & 3.9 & 5.7 & 5.3 & -1.4 & 9.2 \\
\hline Rubber and miscellaneous products & 9.2 & 12.8 & 5.3 & 3.9 & 14.5 \\
\hline Leather and leather products & 14.4 & 59.5 & 20.5 & -6.1 & 34.9 \\
\hline Stone, clay and glass products & 5.6 & 9.5 & 4.7 & 0.9 & 10.3 \\
\hline Primary metal products & 11.2 & 17.4 & 10.6 & 0.6 & 21.8 \\
\hline Fabricated metal products & 7.9 & 8.5 & 8.7 & -0.8 & 16.6 \\
\hline Industrial machinery and equipment & 25.8 & 27.8 & 11 & 14.8 & 36.8 \\
\hline Electronic and other electric equipment & 24.2 & 32.5 & 11.6 & 12.6 & 35.8 \\
\hline Transportation equipment & 17.8 & 24.3 & 15.7 & 2.1 & 33.5 \\
\hline Instruments and related products & 21.3 & 20.1 & 6.3 & 15 & 27.6 \\
\hline Other manufacturing & 13.5 & 41.1 & 9.9 & 3.6 & 23.4 \\
\hline Total manufacturing & 13.4 & 16.3 & 8.2 & 5.2 & 21.6 \\
\hline
\end{tabular}

Source: Campa and Goldberg (1997). 
orientation rate exceeded 5 per cent - the same appreciation resulted in a 6 per cent drop in investment spending.

The measures of Campa and Goldberg can also be used to show the increasing dependence of US industries on the foreign markets. Figure 9.4 charts the changes in the four measures and a measure of our own, which we label industry integration. This last measure adds the export share and imported input share to show the overall, as opposed to net, orientation of US manufacturing industries. Hence, it intends to show the extent of globalization of US manufacturers. Over the three sample periods the measure of industry integration rose 73 per cent, from 12.5 per cent to 21.6 per cent. For all of the measures, the only decline over the entire period is the decline in the export share during the dramatic dollar appreciation of 1985 . None the less, the export share has increased by 60 per cent over the last three decades.

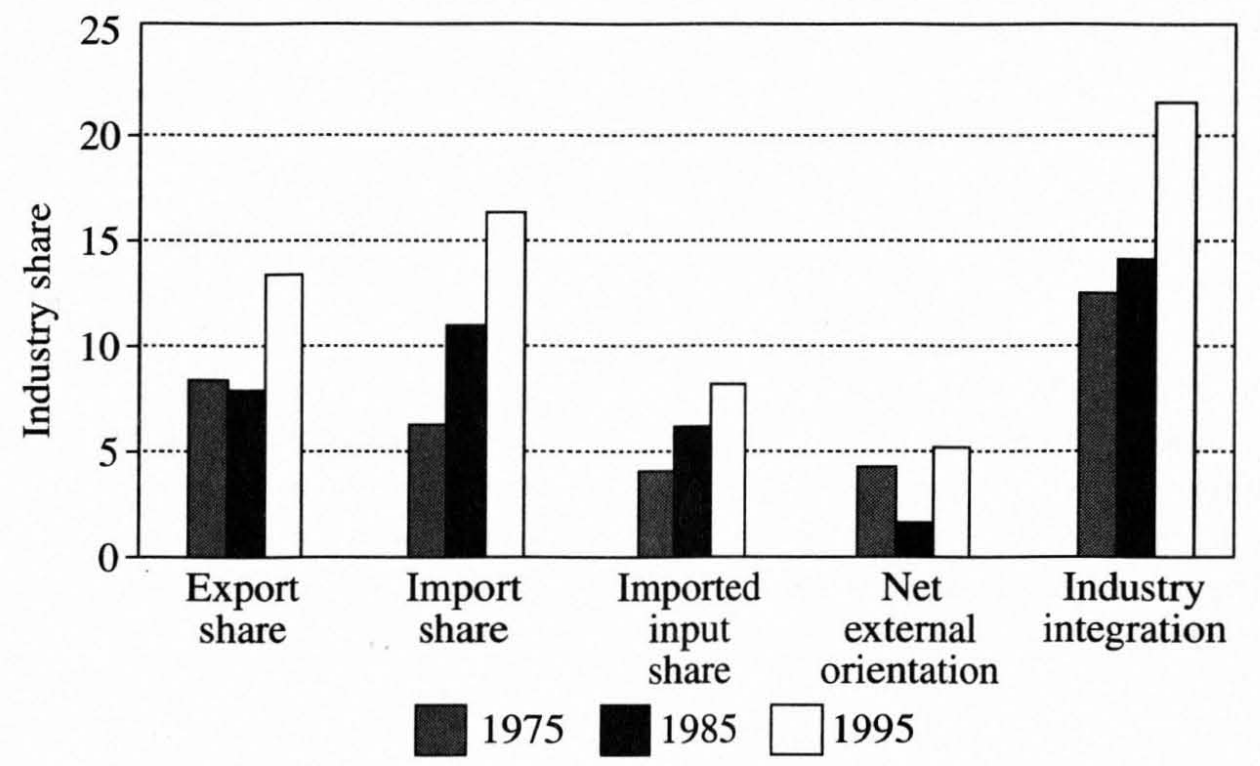

\section{Figure 9.4 Globalization of US industries}

As is also shown in Figure 9.4, the large increase in the export share over the last three decades generated a 21 per cent increase in the net external orientation measure. This is of importance because it means that US manufacturing industries are becoming more sensitive to dollar appreciations. This implies that for most industries when the dollar appreciates, export revenue losses will exceed input cost savings. Hence, exchange rate policy has become more important and US industries should express their concerns and preferences for a stable dollar policy. 


\section{SPILLOVER EFFECTS OF US MONETARY POLICY}

The previous section concluded with evidence of the increasing globalization of US industries. As the US economy becomes increasingly more integrated with foreign economies, and as developing and emerging economies continue to manage their currency values relative to the US dollar, channels for spillover effects of US exchange rate and monetary policies on foreign economies are strengthened. Monetary policy actions, therefore, can affect the exchange and interest rates of trading partners and investor attitudes towards these economies. Hence, the macroeconomic and financial situations of strategically important partners must be considered.

It is reported that the Federal Reserve was inclined to increase interest rates in late 1997, but decided against it because of the fear that it would further destabilize international markets (Obstfeld, 1998). More recently Argentina has floated the notion of dollarization of their economy. In regard to this, the Wall Street Journal (18 January 1999, p. A1) reported that it 'doesn't much matter to the Fed, given that it already has to worry about the international ramifications of anything it does'. It does not appear, however, that the Federal Reserve was as cognizant of the international dimensions of its actions in 1994. In this section we consider an example of the importance of these international dimensions: the 1994 collapse of the Mexican peso.

From 1992 through the first quarter of 1994, Mexico enjoyed rather robust international investment flows to its economy. During 1994, however, Mexico endured a political assassination, the Chiapas uprising and a burgeoning deficit. As if that were not enough, as investors became nervous about the political and economic environment the US Federal Reserve acted to preempt domestic inflation by raising interest rates. To the surprise of many market participants (Federal Reserve Bank of New York Annual Report, p. 16), the Fed increased the Fed Funds Rate by 2.5 percentage points and the discount rate by 1.75 percentage points over the course of the year. As capital flows reversed, Mexican authorities acted to maintain the crawling peg exchange rate arrangement that was in place at the time. Reserves were quickly drawn down and a devaluation was attempted in December 1994. A complete loss of confidence in the peso caused the arrangement to be abandoned in favour of a floating rate system.

A number of empirical studies have concluded that US interest rates have a significant, perhaps even greater than one-to-one, impact on emerging markets (see Frankel and Okongwu, 1995, for a summary of the evidence). Figure 9.5 attempts to illustrate the impact of US interest rate increases on the Mexican exchange rate arrangement. (It is impossible to separate the political assassination with the second interest rate increase as they differ by 


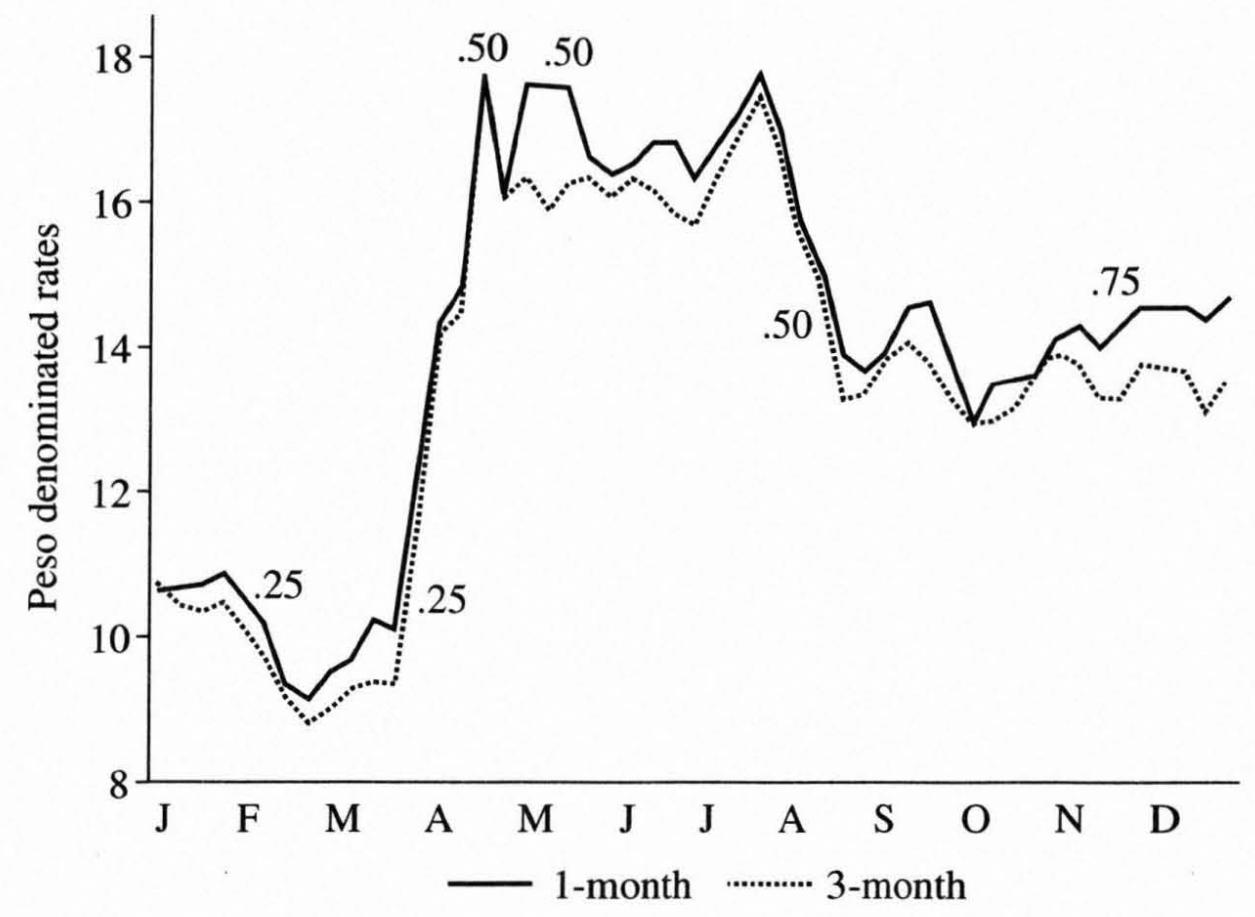

Figure 9.5 1-month and 3-month interest rates: Mexico, 1994

a single day.) Figure 9.5 plots the one-month and three-month rates on pesodenominated government debt and marks the date and size of increases in the Federal Funds Rate. As seen in the figure, there is, in general, an associated increase in Mexican interest rates or sustained high rates following an increase in the Federal Funds rate.

Given the political and economic costs associated with the bail-out monies provided to Mexico in 1995, the Fed and the Treasury have become much more aware of the international dimensions of their actions. The question then becomes: what does this additional responsibility mean for policy-making? Surely it must bring greater stability to the deliberative policy process, not less stability. Further, the potential for policy cooperation and coordination must be considered. Currently the views of the Federal Reserve and the US Treasury revealed in responses to a proposed target zone arrangement for the euro, dollar and yen, and the consideration of dollarizing developing economies, indicate that the United States will encourage cooperation and consultation but not coordination of policies. 


\section{THE EURO: CHALLENGE TO US DOLLAR HEGEMONY AND SEIGNIORAGE REVENUES}

Another linkage between US fiscal policy and the unique position of the dollar is that of seigniorage. Along with the launch of the euro in January 1999 , much speculation has been offered in regard to the challenge to the US dollar hegemony. To be sure, many of the wishes for euro supremacy are political in nature. If the euro does challenge the international use of the dollar, there are economic ramifications as well. In particular, a government that issues fiat money earns seigniorage revenues: that is, the government profits on the difference between the market value of the currency and the cost of actually issuing the currency. There are two principle ways that a government can generate seigniorage revenues: by printing money and by inflating the economy. For the United States, only the first is relevant today.

It is indeed true that seigniorage revenues are a small portion - approximately 3 per cent of overall federal government revenues. None the less, the US Treasury estimates that annual seigniorage revenues for the United States are between $\$ 13$ and $\$ 16$ billion a year. A currency that could challenge dollar hegemony could therefore reduce these sizable seigniorage revenues.

Tavlas (1998) provides the most recent survey data on the international uses of currencies. The data, as shown in Table 9.2, compares the US economy and uses of the dollar with all 15 EU members in aggregate. Though the two economies are relatively the same in terms of share of world GDP and share of world exports, the dollar is dominant in terms of its use as a vehicle currency (use in world trade), in developing country debt and as a reserve currency. Though the European currencies represent three times the turnover of the dollar in foreign exchange markets, the dollar is still the dominant single currency and turns over more than twice that of the next currency, the Deutsche Mark.

If the euro were to replace all EU member country currencies overnight, it still would not be a considerable rival to the dollar in international markets. Tavlas argues, however, that with time the euro will be more stable than any individual European currency as it will denominate all inter-EU trade, European financial markets will deepen and more euro-denominated assets will be issued and the European Central Bank will likely establish its own anti-inflation credentials. Hence, the euro will be needed to properly diversify portfolios and may offer an alternative safe-haven currency. In a static environment, it is likely, therefore, that the euro will challenge dollar hegemony in time. As the proposed dollarization of Argentina shows, however, the world is dynamic and not static, and the importance of the dollar is growing in other areas of the world, not shrinking. 
Table 9.2 United States and European Union: relative size and use of currencies (\%)

United States European Union

\begin{tabular}{lll} 
Economic size & & \\
$\quad$ Share of World GDP, 1996 & 20.7 & 20.4 \\
$\quad$ Share of World Exports, 1996 & 15.2 & 14.7 \\
Use of currencies & & \\
$\quad$ World Trade, 1995 & 51.0 & 31.0 \\
$\quad$ International Bond Offerings, Sept. 1997 & 45.1 & 41.9 \\
$\quad$ Developing Country Debt, year-end 1996 & 50.2 & 15.8 \\
$\quad$ Global Foreign Exchange Reserves, & 63.7 & 19.5 \\
$\quad$ year-end 1996 & & \\
$\quad$ Foreign Exchange Transactions, & 11.5 & 35.0 \\
$\quad$ April 1995 & & \\
\hline
\end{tabular}

Source: Tavlas (1998).

\section{GLOBALIZATION AND WAGE INEQUALITY}

A domestic economic issue particularly central to US experience that has gained greater attention in the 1990s is the issue of income inequality and globalization. The central question is whether increasing trade integration causes or is exacerbating income inequality in the USA. That real income - or wage inequality has increased since the 1970s and especially the 1980s is clear (Gottschalk, 1997). Increased income inequality in the USA is currently understood largely in terms of increased wage inequality, since it is difficult to model the processes leading to changes in the distribution of family income, and since labour economists have well-developed tools with which to analyse changes in the relative demand and supply of low and less skilled labour. Thus among the results of recent research is that changes in mean wage differences between education groups, as reflected in the high school-college premium, and between experience groups explain much of recent increased inequality. The standard interpretation is that labour market forces are driving up the price of skills, adversely affecting high school graduates and those individuals less insulated from market forces by seniority or union coverage. This consequent relative decline in the demand for low and less skilled labour relative to skilled labour has undermined both employment and wages of the former.

Note that this issue particularly confronts the USA on account of generally greater wage flexibility in its labour markets as compared to most other 
OECD countries - with the possible exception of Canada and the UK (Gottschalk and Smeeding, 1997). Most OECD countries have more centralized wage-setting institutions that have permitted them to escape or moderate worldwide trends toward greater income inequality. In addition, they have also relied in recent years more than the USA on tax and transfer systems to offset changes in labour market outcomes where these did tend to produce substantial increases in earnings inequality. This difference indicates that the issue of wage and income inequality not only places special burdens on the USA vis-à-vis its primary trading partners, but especially does so if an important source of this inequality is understood by the public to be the increased global integration of the American economy.

\section{Globalization and Wage Inequality: the Evidence}

In fact, it is probably not the case that the principal cause of this development is increased integration of the US economy through trade. Most research indicates that technological change in the USA since the 1980s has been biased against low-skilled workers, boosting the productivity and wages of the better educated, and that trade has been at best a secondary cause of increased wage inequality (see, for example, Johnson, 1997). Thus in addressing the possible impact of trade on wage and income inequality the research of Lawrence and Slaughter (1993) and Berman et al. (1994) proceeds on the assumption that declines in employment and wages for low-skilled workers are due to within-industry shifts in labour demand due to changes in technology, and that trade operates on inequality only indirectly through between-industry shifts in labour demand. This view that trade plays a lesser role is consistent with the fact that the level of merchandise trade relative to GDP is not high for the USA relative to other industrialized countries.

There are good reasons, however, for thinking that this measure of trade integration may not fully explain the effects of globalization on US employment and wages. First, the rising share of services in GDP and in trade suggests the need for caution in relying on the merchandise share, particularly since trade in services seems to favour higher skilled workers. Second, focusing on the final goods share masks increased trade in intermediate goods and inputs which reflects companies' decisions to outsource increasing amounts of their production processes to take advantage of low-wage labour in other countries. In this case, international trade not only affects labour demand through inter-industry shifts, but trade also affects demand for labour within industries as well, so that globalization arguably plays a more important role than previously thought. We emphasize this latter issue here, since most critics of the idea that increased openness of the US economy is responsible for increased income inequality cite the size of the tradeable goods 
sector as simply being too small to have an impact (for example, Johnson, 1997)..$^{2}$

Outsourcing may be generally understood as the disintegration of the traditional vertically integrated production process, such as characterized Fordist development of manufacturing in the USA in the 20th century, through an increased outsourcing that combines manufacturing or service activities done abroad with those done domestically. In response to opportunities for low-cost production across countries, intermediate inputs may cross borders multiple times before they are marketed as final goods. An important dimension of this process is that independent firms may produce, sell and resell intermediate inputs before final goods emerge under corporate brand names sold in the USA. Thus while the final goods producer with consumer brand name identification and developed marketing structures ends up being responsible for a lengthy, cross-nation, cross-firm 'value chain', it does so by relying on contractual arrangements with independent firms in production locations around the world to increase its flexibility and enhance profitability.

One problem with gaining a better understanding of trade in intermediate inputs is in finding a measure of outsourcing. The strategy of Lawrence (1994) and Krugman (1995) is to focus on multinational firms, the former using imports of US multinationals as a measure of outsourcing, and the latter arguing in terms of flows of foreign direct investment through multinational firms. But a focus on the internal operations of multinational firms alone is not likely to provide a broad enough perspective on outsourcing to be representative of the general situation for the American economy, since outsourcing may involve independent companies selling and reselling semi-finished goods in a larger overall 'value chain'. Feenstra (1998, p. 36) consequently adopts a more general definition of outsourcing that in addition to imports specifically by US multinationals, includes all imported intermediate or final goods that are used in the production of an American firm, or sold under its brand name'.

To construct a data series that reflects the full range of industries and activities included within outsourcing, Feenstra (1998) follows Irwin (1996) in examining what has happened to the composition of US trade using $\mathrm{Bu}$ reau of Economic Analysis 'end-use' categories that assign goods by purchasers rather than production processes, and this is provided in Table 9.3 below. As shown in Table 9.3, across five major categories in which the bulk of trade has historically occurred, the record shows the USA shifting away from agriculture and raw materials and toward manufactured goods. Particularly significant is the fact that the share of capital plus consumer goods together have increased from 10 per cent of imports and 15 per cent of exports in 1925 to over 50 per cent in 1990 . This suggests that what may be termed processed manufactured goods (some of which are sold directly to consumers and some 
Table 9.3 Shares of US exports and imports by end-use categories (\%)

\begin{tabular}{llrrrrr}
\hline Category & & 1925 & 1950 & 1965 & 1980 & 1995 \\
\hline Foods, feeds and & Imports & 21.9 & 30.0 & 19.1 & 11.3 & 5.0 \\
$\quad$ beverages & Exports & 18.7 & 15.5 & 19.2 & 16.9 & 9.2 \\
Industrial supplies and & Imports & 68.2 & 62.4 & 53.3 & 31.3 & 18.2 \\
$\quad$ materials & Exports & 59.8 & 45.5 & 34.8 & 32.2 & 25.6 \\
Capital goods (except & Imports & 0.4 & 1.3 & 7.1 & 19.0 & 33.6 \\
autos) & Exports & 8.7 & 22.4 & 31.4 & 35.0 & 42.4 \\
Consumer goods & Imports & 9.4 & 6.1 & 16.0 & 21.5 & 24.3 \\
$\quad$ (except autos) & Exports & 6.0 & 8.9 & 7.0 & 7.8 & 11.7 \\
Automotive vehicles & Imports & 0.02 & 0.3 & 4.5 & 16.9 & 18.9 \\
and parts & Exports & 6.8 & 7.8 & 7.5 & 8.1 & 11.2 \\
\hline
\end{tabular}

Source: Feenstra (1998).

of which will receive additional value added by American firms) now play an increasingly important role in US trade, and that more products are being imported into the USA at various stages of processing.

To further investigate this hypothesis, Feenstra and Hanson (1997) consider the ratio of imported to domestic intermediate inputs for US manufacturing industries, and find that imported inputs have increased from 5.7 per cent of total intermediate purchases in $\mathbf{1 9 7 2}$ to 13.9 per cent in 1990. Similar calculations by Campa and Goldberg (1997) for Canada, Japan, the UK and the USA show a doubling of the share of imported inputs for the USA between 1975 and 1995 for all manufacturing. Hummels et al. (1997), who use the term 'vertical specialization' to describe a country's specialization in particular segments of the value chain, also find the USA to have higher values of vertical specialization in 1990 as compared to 1970 .

\section{Policy Implications}

Further research on the impact of outsourcing on wages still needs to be done, but there is enough evidence to suggest that outsourcing may contribute to a reduction in relative demand for low-skilled labour in developed countries beyond what trade in final goods contributes. How important, then, is this connection between globalization and wage inequality? Perhaps representative of the general view on the effects of trade per se is Richardson (1995, p. 51): 'My own reading of this research is that trade is a moderate contributing source of income inequality trends; it may not overshadow other sources, but it cannot be shrugged away.' Taken together with the additional impact of outsourcing, 
this suggests that Americans are likely to place pressure on policy-makers to somehow protect those affected adversely by increasing integration. But the situation is more complicated. Recognizing that those production activities lost by more developed countries are typically gained by less developed countries, and that outsourced activities are low skilled, labour intensive for developed countries and high skilled, labour intensive for developing countries, we see that outsourcing raises the average skill-intensity of production in both locations, and assists the general tendency toward factor price equalization with respect to wages between developed and developing countries that trade in final goods involves. Thus, lying in the balance for policy-makers with increasing US wage inequality is the prospect of increasing wage equality in low-income US trading partners. Were this to help move developing economies towards the size of developed economies, according to the arguments of Hummels. and Levinsohn (1995), we might expect an even faster growth of world trade with the prospect of rapidly increasing gains from trade. These possibilities suggest that policy-makers will be disinclined to adopt second-best initiatives that attempt to 'tame trade', and will rather favour 'first-best' strategies for compensating those possibly affected by the economy's greater openness. ${ }^{3}$

In welfare and efficiency terms, this might first be formulated in terms of Corden's (1997) 'conservative social welfare function' that precludes significant reductions in real income of important sections of the community through trade adjustment assistance directly targeted on those adversely affected by increasing trade integration. Using a labour economics perspective, a longrun strategy to offset the reduction in demand for low-skilled workers through a parallel reduction in their supply is for government action to improve education and training. In the short run, subsidies to boost living standards of workers who take low-paying jobs may take the form of tax cuts, cash supplements to wages, improved public services and subsidies to employers to hire workers in non-traded services (Wood, 1994). An important problem is that in either case these policies in the USA would impose fiscal burdens at the federal level precisely at a time when federal budgets are being reduced rather than expanded, and when the majority of citizens are most concerned about anticipated funding shortfalls for social security and medicare. Indeed, from an intergenerational perspective on budgets rather than the traditional annual one normally taken, the fiscal liability for future social security and medicare benefits place the budget in deficit through the current 10 year projections. ${ }^{4}$ Thus, the USA appears to be operating with a federal 'budget constraint' that makes significant trade adjustment assistance unlikely, and one cannot consequently rule out the possibility that political pressures may build for protection.

But might trade adjustment assistance somehow pay for itself? Phelps (1997) has recently argued that a wage subsidy directed at low-skilled work- 
ers might pay for itself through savings on social expenditures and increased tax revenues. Rather than revenue-neutral, such subsidies might be 'revenue-positive', and actually help the USA address its future fiscal imbalance. More research needs to be done to demonstrate the viability of this strategy if the USA is to resist popular demands for protecting low-skilled workers.

\section{CONCLUSIONS}

Here we offer three broad conclusions about the nature and direction of American macromanagement in a period of globalization. First, it is important to be aware of how the size and relative autonomy of the American economy tends to narrow the focus of policy-makers on domestic concerns. With respect to exchange rate and monetary policy, this is manifest in a notalways benign neglect toward the impact of managing the value of the dollar on both domestic business and foreign economies. At the opposite extreme is a perhaps too strong concern with addressing wage inequality. In a society accustomed to thinking in domestic terms, the tendency to focus strictly on the American side of trade in the form of increasing wage dispersion pushes the experience in developing economies, their decreasing wage dispersion and possible increased gain from trade, out of view.

Second, it is important to remember that the policy-making process always reflects a political balancing of competing interests, so that what may be the most rational policy in any given circumstance is less the point than what reconciling competing interests may achieve. Our argument in this connection is that having a unified exchange rate and monetary policy has been hobbled by the inability of competing interests to reach agreement about the value of the dollar. But the fractionalization of business interests, together with an increasing awareness of the effects on other countries of US policy, may now lead the USA toward a more consistent strategy towards the dollar, and one, moreover, that attempts to stabilize its value along with stabilizing prices.

Third, our view is that first-best, non-protectionist policy that targets particular problems directly, as would wage subsidies for low-skilled workers, remains a consensus view among US policy-makers. This is not to say that protectionist thinking does not represent a danger in the USA. Rather it is to say that protectionist thinking is largely confined to industries, firms and sectors of the population interested in their own case alone, and does not constitute a view of the best interest of the country as a whole. Of course, enough voices adversely affected by trade in some circumstances can together constitute a majority. Whether this is prevented from happening may 
depend in part on the success of trade adjustment policies that pay for themselves in a period of constrained fiscal budgets.

\section{NOTES}

1. The relatively small current account deficit of 1991 reflects a surplus in the unilateral transfers category that resulted from receipts from Gulf War allies.

2. Another approach for estimating the effects of trade on labour markets, and thus showing a link between globalization and wage inequality, is the factor content approach used by Wood (1994). See Leamer (1994) for a critique of Wood's results.

3. For a minority view favouring protection and trade barriers see Batra (1993). For an intermediate view recommending moderating the pace of globalization, see Rodrik (1997).

4. In particular, it has been estimated that social security benefits promised to the working population today may exceed the taxes this population will pay for these benefits by seven to ten trillion dollars in present value terms (Feldstein, 1998).

\section{REFERENCES}

Batra, Ravi (1993), The Myth of Free Trade, New York: Scribner.

Berman, Eli, John Bound and Zvi Griliches (1994), 'Changes in the demand for skilled labor within U.S. manufacturing: evidence from the annual survey of manufacturers', Quarterly Journal of Economics, 109 (2), 367-98.

Campa, José and Linda Goldberg (1997), 'The evolving external orientation of manufacturing: a profile of four countries', Federal Reserve Bank of New York, Economic Policy Review, July, 53-81.

Corden, Max (1997), Trade Policy and Economic Welfare, 2nd edition, Oxford: Clarendon Press.

The Economist (1998), 'Saving disgrace', 14 November, 80.

The Economist (1999), 'Liberalism lives', 2 January, 59-60.

Faust, Jon (1989), 'U.S. foreign indebtedness: are we investing what we borrow?', Federal Reserve Bank of Kansas City, Economic Review, July, 3-20.

Federal Reserve Bank of New York (1994), Annual Review.

Feenstra, Ronald (1998), 'Integration of trade and disintegration of production in the global economy', Journal of Economic Perspectives, 12 (4), 31-50.

Feenstra, Ronald and Gordon Hanson (1997), 'Foreign Investment, Outsourcing and Relative Wages', in R.C. Feenstra, G.M. Grossman and D.A. Irwin (eds), The Political Economy of Trade Policy: Papers in Honor of Jagdish Bhagwati, Cambridge, MA: MIT Press.

Feldstein, Martin (1998), Privatizing Social Security, Chicago: University of Chicago Press.

Frankel, Jeffrey and Chudozie Okongwu (1995), 'Liberalized portfolio capital inflows in emerging markets: sterilization, expectations, and the incompleteness of interest rate convergence', International Journal of Finance and Economics, VI, 1-23.

Goldberg, Linda and Keith Crockett (1998), 'The dollar and U.S. manufacturing', Federal Reserve Bank of New York, Current Issues in Economics and Finance, 4 (12). 
Gottschalk, Peter (1997), 'Inequality, income growth, and mobility: the basic facts', Journal of Economic Perspectives, 11 (2), 21-40.

Gottschalk, Peter and Timothy M. Smeeding (1997), 'Cross-national comparisons of earnings and income inequality', Journal of Economic Literature, 35 (2), 633-87.

Hakkio, Craig (1995), 'The U.S. current account: the other deficit', Federal Reserve Bank of Kansas City, Economic Review, Third Quarter, 11-24.

Henning, Randall (1994), Currencies and Politics in the United States, Germany, and Japan, Washington, DC: Institute for International Economics.

Higgins, Matthew and Thomas Klitgaard (1998), 'Viewing the current account deficit as a capital inflow', Current Issues in Economics and Finance, Federal Reserve Bank of New York, 4 (13), December.

Hirsh, Michael (1997), 'Looking Upward', Newsweek, 23 June, 12-16.

Hummels, David and James A. Levinsohn (1995), 'Monopolistic competition and international trade: reconsidering the evidence', Quarterly Journal of Economics, 110 (3), 799-836.

Hummels, David, Dana Rapoport and Kei-Mu Yi (1997), 'Globalization and the Changing Nature of World Trade', University of Chicago, Federal Reserve Bank of New York and Rice University.

Humpage, Owen (1998), 'Is the current account deficit sustainable?', Economic Commentary, Federal Reserve Bank of Cleveland, 15 October.

Irwin, Douglas (1996), 'The United States in a new world economy? A century's perspective', American Economic Review, 86 (2), 41-51.

Johnson, George E. (1997), 'Changes in earnings inequality: the role of demand shifts', Journal of Economic Perspectives, 11 (2), 41-54.

Krugman, Paul (1995), 'Growing world trade: causes and consequences', Brookings Papers on Economic Activity, 1, 327-62.

Lawrence, Robert (1994), 'Trade, Multinationals and Labour', in Philip Lowe and Jacqueline Dwyer (eds), International Integration of the Australian Economy, Sydney: Reserve Bank of Australia, pp. 23-65.

Lawrence, Robert Z. and Matthew J. Slaughter (1993), 'International Trade and American Wages in the 1980s: Giant Sucking Sound or Small Hiccup?', Brookings Papers on Economic Activity: Microeconomics, pp. 161-226.

Learner, Edward E. (1994), 'Trade, Wages and Revolving-Door Ideas', NBER Working Paper no. 4716.

Obstfeld, Maurice (1998), 'The Global Capital Market: Benefactor or Menace?', Journal of Economic Perspectives, 12 (4), 9-30.

Phelps, Edmund (1997), Rewarding Work, Cambridge, MA: Harvard University Press.

Richardson, J. David (1995), 'Income inequality and trade: how to think, what to conclude', Journal of Economic Perspectives, 9 (3), 33-55.

Rodrik, Dani (1997), Has Globalization Gone Too Far?, Washington, DC: Institute for International Economics.

TavIas, George (1998), 'The international use of currencies: the U.S. dollar and the euro', Finance and Development, 35 (2), June.

The Wall Street Journal (1999), 'Argentina considers a radical peso defense: use dollars instead', 18 January, p. A1.

Wood, Adrian (1994), North-South Trade, Employment and Inequality: Changing Fortunes in a Skill-Driven World, Oxford: Clarendon Press. 